\title{
Pengaruh Lingkungan Kerja Terhadap Kepuasan Karyawan Dan Implementasinya Terhadap Kinerja Karyawan Pada PT. PLN ( Persero ) UPDK Mahakam Samarinda
}

\author{
Armini Ningsih $^{1 *}$, Syachrul $^{2}$, Tia Ratnasari ${ }^{3}$ \\ ${ }^{123}$ Program Studi Administrasi Bisnis, Politeknik Negeri Samarinda, Samarinda 75131 \\ *Correspondent Author \\ E-mail: syachrulborneo@gmail.com
}

Diterima: 20 Pebruari 2019 Direvisi: 21 April 2019 Disetujui: 25 Mei 2020

\begin{abstract}
Abstrak
Pengaruh Lingkungan Kerja Terhadap Kepuasan Kerja dan Implikasinya Terhadap Kinerja Karyawan pada PT PLN (Persero) UPDK Mahakam Penelitian ini bertujuan untuk mengetahui pengaruh lingkungan kerja terhadap kepuasan kerja dan impilikasinya terhadap kinerja karyawan pada PT PLN (Persero) UPDK Mahakam. Dengan subjek penelitian ini adalah semua karyawan bagian PT PLN (Persero) UPDK Mahakam dengan jumlah 40 orang. Pengumpulan data menggunakan kuesioner yang telah diuji validitas dan reliabilitasnya sedangkan analisis data dilakukan dengan menggunakan analisis regresi linear berganda. dengan alat analisis Path Analisis menggunakan Smart PLS, dan SPSS.Hasil penelitian menunjukkan bahwa: 1) Variabel Lingkungan Kerja (X1) berpengaruh signifikan terhadap Kepuasan Kerja (Y1) pada PT PLN (Persero) UPDK Mahakam, 2) Variabel Lingkungan Kerja (X1) berpengaruh tidak signifikan terhadap Kinerja Karyawan (Y2) pada PT PLN (Persero) UPDK Mahakam, 3) Variabel Kepuasan Kerja (Y1) berpengaruh signifikan terhadap Kinerja Karyawan (Y2) pada PT PLN (Persero) UPDK Mahakam.
\end{abstract}

Kata kunci: Lingkungan Kerja, Kepuasan Kerja dan Kinerja Karyawan

\begin{abstract}
The Effect of Work Environment on Job Satisfaction and Its Implications on Employee Performance at PT PLN (Persero) UPDK Mahakam This research aims were to determine the effect of work environment on job satisfaction and its impact on employee performance at PT PLN (Persero) UPDK Mahakam. With the subject of this study were all employees of PT PLN (Persero) UPDK Mahakam with a total of 40 people. Data collection used in this research was a questionnaire that has been tested for validity and reliability while data analysis was done using multiple linear regression analysis. with Path Analysis tools using Smart PLS, and SPSS. The results showed that: 1) Work Environment Variable (X1) had a significant effect on Job Satisfaction (Y1) at PT PLN (Persero) UPDK Mahakam, 2) Work Environment Variables (XI) insignificant effect on Employee Performance (Y2) at PT PLN (Persero) UPDK Mahakam, 3) Job Satisfaction Variable (Y1) significantly influenced the Employee Performance (Y2) at PT PLN (Persero) UPDK Mahakam.
\end{abstract}

Keywords: Work Environment, Job Satisfaction and Employee Performance

\section{PENDAhuluaN}

Setiap perusahaan atau instnsi selalu memiliki tujuan yang ingin dicapai, serta kaitannya dengan kesejahteraaan masyarakat adalah melalui terciptanya kesejahteraan bagi karyawan.Karyawan adalah sumber daya manusia yang diharapkan menjadi entrepreneur. 
Lingkungan kerja merupakan tempat dimana para karyawan melakukan aktivitas bekerja.lingkungan kerja dapat membawa positif dan negatif bagi pegawai dalam rangka mencapai hasil kerjanya. lingkungan kerja disuatu instansi sangat penting untuk diperhatikan manjemennya. lingkungan kerja yang memusatkan bagi karyawannya dapat meningkatkan kinerja. sebaliknya lingkungan kerja yang tidak memadai akan dapat menurunkan kinerja.lingkungan kerja yang baik adalah yang aman, tentaram, bersih, tidak bising, terang dan bebas dari segala macam ancaman dan gangguan yang dapat menghambat karyawan untuk bekerja secara optimal.Rasa nyaman dan aman akan tercipta karena lingkungan kerja yang memadai.

Lingkungan kerja salah satu penyebab dari keberhasilan dalam melaksanakan suatu pekerjaan tetapi juga dapat menyebabkan suatu kegagalan dalam pelaksanaan suatu pekerjaan, karena lingkungan kerja dapat mempengaruhi pekerja, terutama lingkungan kerja yang bersifat fisikoligis.sedangkan pengaruhnya itu sendiri dapat bersifat positif dan dapat bersifat negatif.Lingkungan kerja dapat memepengaruhi emosi karyawan. Jika pegawai menyenangi lingkungan kerja dimana dia bekerja, maka pegawai tersebut akan betah ditempat kerjanya untuk melakukan aktivitas sehingga waktu kerja dipergunakan secara efektif dan optimis prestasi kerja pegawai juga tinggi. (Syarif, 2015) Menurut Barry Render \& Jay Heizer (2001:239), Lingkungan kerja merupakan lingkungan fisik tempat karyawan berkerja yang mempengaruhi kinerja, keamanan dan mutu kehidupan kerja mereka.Menurut Mardianan (2005:15)"Lingkungan Kerja adalah lingkungan dimana pegawai melakukan pekerjaanya sehari-hari". Lingkungan kerja yang kondusif memberikan rasa aman dan memungkinkan para pegawai untuk dapat bekerja optimal sehingga menimbulkan rasa puas(Syarif, 2015).

Selain Lingkungan Kerja hal yang harus diperhatikan yaitu Kepuasan kerja.Menurut Ifah Lathifah (2008) dalam Wibowo (2012) Kepuasan kerja merupakan salah satu faktor yang sangat penting untuk mendapatkan hasil kerja yang optimal. Ketika seorang merasakan kepuasan dalam bekerja tentunya ia akan berupaya semaksimal mugkin dengan segenap kemampuan yang dimilikinya untuk menyelesaikan tugas pekerjaannya.

Kepuasan kerja pada seorang pegawai mempengaruhi kehadirannya dalam pekerjaan, kesediaan untuk bekerja juga seringkali dipengaruhi oleh keinginannya untuk mengganti pekerjaan (Setiawan, 2012). Pegawai dengan kepuasan tinggi akan memberikan kontribusi tinggi terhadap perusahaan (Setiawan,2012). Atas kontribusi yang tinggi tersebut, maka org anisasi akan memiliki outcomes yang tinggi, dan dengan outcomes yang tinggi maka organisasi dapat memenuhi keinginan dan harapan balas jasa yang layak pada diri pegawai (Setiawan,2012). Kepuasan kerjayang tinggi diinginkan oleh para manager karena dapat dikaitkan dengan hasil positif yang mereka harapkan (Davis, 1985 dalam Rosa, 2004).

Selain Lingkungan dan kepuasan kerja, salah satu hal yang perlu diperhatikan adalah tentang kinerja karyawan.Kinerja karyawan yaitu tingkat pencapaian atau hasil kerja seseorang dari sasaran yang harus dicapai

Hal ini juga dapat mempengaruhi tingkat keberhasilan suatu instansi pemerintahan dalam mencapai tujuan instansi adalah kinerja pegawainnya.Kinerja yang baik adalah kinerja yang optimal, yaitu kinerja yang sesuai standar organisasi dan mendukung tercapainya tujuan organisasi. Menurut Haris Munandar (1997:68) "Kinerja adalah suatu yang dicapai, prestasi yang dilihatkan tentan kemampuan kerja pegawai sehingga menghasilkan sesuatu yang optimal",

PT PLN (Persero) merupakan suatu Badan Usaha Milik Negara (BUMN) yang bergerak dibidang ketenagalistrikan, dan merupakan salah satu perusahaan listrik di Indonesia. PT PLN (Persero) terdiri dari beberapa wilayah di Indonesia, salah satunya adalah PT PLN (Persero) Wilayah Kalimantan Timur dan Utara yang terdiri dari 8 unit pelaksana salah satunya PT PLN (Persero) UPDK Mahakam. PT PLN (Persero) UPDK Mahakam merupakan unit pelaksana yang bergerak dibidang pembangkitan. Pada tanggal 10 Oktober 1996 UPDK Mahakam beralamatkan di Jl. Tengkawang Samarinda, kemudian pada tanggal 15 Desember 1997 kantor berpindah alamat ke PLTGU Tanjung Batu. Pada tahun 2004 kantorUPDK Mahakam pindah ke Jl. Ulin No. 1 Samarinda hingga saat ini. 
Fenomena yang terjadi tiga tahun terakhir adalah adanya pelanggaran disiplin yaitu tidak tepat masuk kerja setelah cuti.setelah dilakukannya investigasi ternyata pegawai yang melakukan pelanggaran karena tidak merasa cocok dengan lingkungan kerjanya atau tentang hubungan dengan atasan dan bawahan yang kurang baik.dan KWH yang dihasilkan tiga tahun terakhir yakni tahun 2016 sebanyak 359.835.6772,0000. ditahun 2017 sebanyak 267.791.046,6580. dan ditahun 2018 sebanyak 424.928.894,0000 KWH yang dihasilkan.lingkungan kerja yang pernah terjadi yang terjadi yang sekarang ini banyak berunculan bermacam-macam masalah baik dalam skala kecil, menengah, maupun skala yang lebih besar dikarenakan pegawainya tidak bisa menyesuaikan diri dengan lingkungannya dan kurangnya memperhatikan dan menjaga lingkungan kerja sehingga menyebabkan menurunya Kepuasan Kerja pegawai dalam mencapai tujuan perusahaan. Maka instansi tersebut harus menciptakan kondisi yang dapat mendorong dan memungkinkan pegawai untuk mengembangkan dan meingkatkan serta keterampilan yang dimiliki secara optimal. Oleh karena itu dilakukan penelitian untuk mengetahui bagaimana pengaruhlingkungan kerja dan kepuasan kerja terhadap kinerja Pegawai pada PT.PLN (Persero) UPDK Mahakam. Berdasarkan penemuan masalah tersebut di atas, tujuan penelitiannya untuk mengetahui pengaruh lingkungan kerja berpengaruh signifikan terhadap kepuasan kerja pada PT PLN (Persero) UPDK Mahakam, untuk mengetahui pengaruh lingkungan kerja berpengaruh signifikan terhadap kepuasan kerja pada PT PLN (Persero) UPDK Mahakam, untuk mengetahui pengaruh kepuasan kerja berperngaruh signifikan terhadap kinerja karyawanpada PT PLN (Persero) UPDK Mahakam.

Menurut Bohlander dan Snell (2014:4) manajemen sumber daya manusia yakni suatu ilmu yang mempelajari bagai mana memberdayakan karyawan dalam perusahaan, membuat pekerjaan, kelompok kerja, mengembangkan para karyawan yang mempunyai kemampuan, mengidentifikasikan suatu pendekatan untuk dapat mengembangkan kinerja karyawan dan memberikan imbalan kepada mereka atas usahanya dalam bekerja. Dari beberapa pengertian menurut para ahli diatas dapat disimpulkan bahwa Manajemen Sumber Daya Manusia yaitu ilmu yang mempelajari tentang memberdayakan karyawan dalam perusahaan dengan cara penarikan, seleksi, pengembangan, pemeliharaan. dan penggunaan sumber daya manusia untuk mencapai tujuan-tujuan baik individu maupun organisasi.

\section{Definisi Lingkungan}

Menurut Undang-undang Nomor 32 tahun 2009 tersirat bahwa lingkungan hiduplah yang mempengaruhi mahkluk hidup, termasuk di dalamnya manusia.Manusia hendaknya menyadari kalau alamlah yang memberi kehidupan dan penghidupan, baik secara langsung maupun tidak langsung.(Sridianti, 2018).

Menurut Prof DR.IR.Otto Soemarwoto (2001) Lingkungan hidup adalah jumlah semua benda dan kondisi yang ada dalam ruang yang kita tempati yang mempengaruhi kehidupan kita. Menurut Prof.DR.ST.Munadjat Danusaputro,SH (1980) Dari beberapa pengertian menurut para ahli diatas dapat disimpulkan bahwa Lingkungan adalahtempat, benda dan kondisi yang di didalamnya terdapat manusia dan segala tingkah laku yang mempengaruhi kehidupan.

\section{Definisi Kepuasan Kerja}

Kepuasan kerja adalah sikap umum terhadap pekerjaan seseorang, yang menunjukkan perbedaan antara jumlah penghargaan yang diterima pekerja dan jumlah yang mereka yakini seharusnya mereka terima (Robbiins dalam Desi Puspta Prabandari, 2015:16) Kepuasan kerja adalah sikap emosional yang menyenangkan dan mencintai pekerjaannya (Hasibuan M. , 2012). Menurut(Robbins, 2006) kepuasan kerja adalah sikap umum terhadap pekerjaan seseorang yang menunjukkan perbedaan antara jumlah penghargaan yang diterima dan jumlah yang diyakini seharusnya mereka terima.

\section{Definisi Kinerja Pegawai}

Kinerja sangatlah penting dalam suatu perusahaan/instansi untuk mendorong keinginan dan lebih meningkatkan kenerja karyawan yang lebih baik. Istilah kinerja berasal dari Job Performance atau Actual Performance (prestasi kerja atau prestasi sesungguhnya yang dicapai oleh seseorang). Menurut Veizal (2004:223) "kinerja adalah merupakan perilaku yang nyata yang 
ditampilakn setiap orang sebagai prestasi kerja yang dihasilakan oleh karyawan sesuai degan peranannya dalam perusahaan".

\section{Hipotesis}

Hipotesis adalah satu dugaan yang bersifat sementara dari suatu masalah, sehinga hipotesis sangatlah membatu dalam dalam laporan. Sehubungan dengan hal tersebut maka penulis dapat mengemukan bahwa hiotesis dalam laporan ini adalah:

a. Diduga Lingkungan Kerja mempengaruhi Kepuasan Kerja pada PT PLN (Persero) UPDK Mahakam

b. Diduga Lingkungan Kerja mempengaruhi kinerja karyawanpada PT PLN (Persero) UPDK Mahakam

c. Diduga Kepuasan Kerja mempengaruhi Kinerja Karyawan pada PT PLN (Persero) UPDK Mahakam

\section{Indikator Variable}

Tabel 1. Indikator Lingkungan Kerja

\begin{tabular}{|c|c|}
\hline No & Indikator Lingkungan Kerja \\
\hline $\mathrm{X} 1.1$ & Suasana kerja \\
\hline $\mathrm{X} 1.2$ & Hubungan dengan rekan kerja \\
\hline $\mathrm{X} 1.3$ & Hubungan atasan dengan karyawan \\
\hline $\mathrm{X} 1.4$ & Fasilitas kerja \\
\hline
\end{tabular}

Tabel 2. Indikator Kepuasan Kerja

\begin{tabular}{|c|c|}
\hline No & Indikator Kepuasan Kerja \\
\hline Y1.1 & Gaji \\
\hline Y1.2 & Lingkungan kerja \\
\hline Y1.3 & Hubungan dengan rekan kerja \\
\hline Y1.4 & Atasan \\
\hline Y1.5 & Promosi jabatan \\
\hline
\end{tabular}

Tabel 3. Indikator Kinerja Karyawan

\begin{tabular}{|c|l|}
\hline No & \multicolumn{1}{|c|}{ Indikator Kinerja Karyawan } \\
\hline Y2.1 & Target yang ditetapkan tercapai \\
\hline Y2.2 & Pelaksanaan pekerjaan tepat waktu \\
\hline Y2.3 & Menghasilkan kerja yang berkualitas \\
\hline
\end{tabular}

\section{METODOLOGI}

\section{Populasi , Sampel dan Pengumpulan Data}

Populasi menurut Sugiyono (2010:117) populasi adalah wilayah generalissi yang terdiri atas obyek/subyek yang mempunyai kualitas dan karakteristik tertentu yang diterapkan oleh peneliti untuk dipelajari dan kemudian ditarik kesimpulannya.Populasi dalam penelitian ini adalah seluruh karyawanpada PT PLN (Persero) UPDK Mahakam yang berjumlah 40 orang.

\section{Sampel}

Menurut (Arikunto, Prosedur Penelitian Suatu Pendekatan Praktik, 2006)menyatakan : "sampel adalahsebagaian atau wakil populasi yang diteliti”. Untuk sekedat ecer-ecer, apabila subjeknya kurang dari 100 lebaih baik diambil semua sehingga penelitinnya merupakan penelitian populasi.Tetapi, jika jumlah subjeknya besar, dapat di ambil antara 1-15\% atau 20-25\% atau lebih.Dari pendapat tersebut peneliti menggunakan keseluruan populasi sebagai sampel penelitian ini. 


\section{Teknik Pengumpulan Data}

Teknik pengumpulan data adalah cara pengumpulan data baikdata primer maupun skunder, oleh penulis dalam menyelesaikan laporan tugas akhir. Adapun teknik pengumpulan data yang penulis laksanakan adalah dengan cara menggunakan peneltian perpustakaan dan kuesioner.

\section{Uji Validitas}

Menurut (Sugiyono, Metode Penelitian Kuantitatif Kualitatif dan R\&D, 2012) instrumen yang valid berarti alat ukur yang digunakan untuk mendapatkan data (mengukur) itu valid. Valid berarti instrumen tersebut dapat digunakan untuk mengukur apa yang seharusnya diukur.

Menurut (Arikunto S. , 2006) untuk menguji validitas instrumen digunakan rumus korelasi Product Moment yang dikemukakan oleh Pearson dengan rumus:

$$
r_{x y}=\frac{N \sum X Y-\left(\sum X\right)\left(\sum Y\right)}{\sqrt{\left(N \sum X^{2}-\left(\sum X\right)^{2}\right)\left(N \sum Y^{2}-\left(\sum Y\right)^{2}\right)}}
$$

Keterangan:

$$
\begin{array}{ll}
r_{x y}=\text { indeks korelasi pearson } & \mathrm{Y}=\text { skor total item pertanyaan } \\
\mathrm{N} & =\text { banyaknya sampel }
\end{array}
$$$$
\mathrm{X}=\text { skor item pertanyaan }
$$

Dengan kriteria pengujian jika korelasi antar butir dengan skor total lebih dari 0,3 maka instrumen tersebut dinyatakan valid atau sebaliknya jika korelasi antar butir dengan skor total kurang dari 0,3 maka instrumen tersebut dinyatakan tidak valid. Jika $r_{\text {hitung }}>r_{\text {tabel }}$ dengan $\alpha=0,05$ maka koefisien korelasi tersebut signifikan.

Menurut(Sugiono, Metode Penelitian Kuantitatif Kualitatif dan R\&D, 2012) butir yang mempunyai korelasi positif dengan kriterium (skor total) serta korelasi yang tinggi, menunjukkan bahwa butir tersebut mempunyai validitas yang tinggi pula. Syarat minimum untuk dianggap memenuhi syarat adalah jika $\mathrm{r}=0,3$.

\section{Uji Reabilitas}

Instrumen yang reliabel belum tentu valid. Instrumen yang reliabel adalah instrumen yang bila digunakan beberapa kali untuk mengukur objek yang sama, akan menghasilkan data yang sama. Perhitungan untuk mencari harga reliabilitas instrumen didasarkan pada pendapat Arikunto (2006:109) yang menyatakan bahwa untuk menghitung reliabilitas dapat digunakan rumus Spearman Brown, yaitu:

$$
R=\frac{2 r}{1+r}
$$

Keterangan:

$r \quad=$ Hasil Korelasi

$\mathrm{R} \quad=$ Reliabilitas

Uji reliabilitas merupakan indeks yang menunjukkan sejauh mana alat pengukuran dapat dipercaya atau diandalkan.Reliabilitas instrumen diperlukan untuk mendapatkan data sesuai dengan tujuan pengukuran.Untuk mencapai hal tersebut, dilakukan uji reliabilitas dengan model Alpha Cronbach's yang diukur berdasarkan skala Alpha Cronbach's 0 sampai 1.

\section{Uji Hopotesis}

Uji t digunakan untuk menguji signifikasi konstanta dari variabel bebas secara parsial atau individual terhadap variabel terikat. Pengujian ini dilakukan dengan cara membandingkan nilai $t$ hitung dengan $t$ tabel. Apabila $t$ hitung $>t$ tabel dengan signifikasi dibawah 0,05 (5\%), maka 
secara parsial atau individual variabel bebas berpengaruh signifikasi terhadap variabel terikat, begitu juga sebaliknya.

Rumus yang ditemukan oleh (Sugiyono, Metode Penelitian, 2004) untuk mengetahui $t$ hitung, adalah sebagai berikut:

$$
t=\frac{b_{1}}{S b_{1}}
$$

Keterangan:

$$
\begin{array}{ll}
\mathrm{b}_{1} & =\text { Koefisien regresi } \\
\mathrm{Sb}_{1} & =\text { Standar } \text { error } \text { koefisien regresi }
\end{array}
$$

Kriteria pengambilan keputusan:

Ketentuan :

Apabila $r_{\text {hitung }}>r_{\text {tabel, }}$ maka Ho ditolak Ha diterima

Apabila $r_{\text {hitung }}>r_{\text {tabel, }}$ maka Ho diterima dan Ha ditolak.

\section{Uji Reliability}

Tabel 1. Uji Realibility

\begin{tabular}{|c|c|c|c|c|c|}
\hline & $\begin{array}{l}\text { Scale Mean } \\
\text { if item } \\
\text { Deleted }\end{array}$ & $\begin{array}{l}\text { Scale } \\
\text { Variance if Item } \\
\text { Deleted }\end{array}$ & $\begin{array}{l}\text { Corrected } \\
\text { Item-Total } \\
\text { Correlation }\end{array}$ & $\begin{array}{l}\text { Croncach's } \\
\text { Alpha it Item } \\
\text { Deleted }\end{array}$ & Keterangan \\
\hline $\mathrm{X} 1.1$ & 45.43 & 32.199 & .432 & .910 & Reliabel \\
\hline $\mathrm{X} 1.2$ & 45.63 & 30.446 & .573 & .905 & Reliabel \\
\hline $\mathrm{X} 1.3$ & 45.70 & 29.190 & .625 & .903 & Reliabel \\
\hline $\mathrm{X} 1.4$ & 45.73 & 29.846 & .562 & .907 & Reliabel \\
\hline Y1.1 & 45.53 & 30.922 & .553 & .906 & Reliabel \\
\hline Y1.2 & 45.40 & 31.785 & .645 & .903 & Reliabel \\
\hline Y1.3 & 45.43 & 28.661 & .775 & .895 & Reliabel \\
\hline Y1.4 & 45.45 & 30.254 & .747 & .898 & Reliabel \\
\hline Y1.5 & 45.50 & 29.949 & .676 & .900 & Reliabel \\
\hline Y2.1 & 45.43 & 28.661 & .775 & .895 & Reliabel \\
\hline Y2.2 & 45.45 & 30.254 & .747 & .898 & Reliabel \\
\hline Y2.3 & 45.50 & 29.949 & .676 & .900 & Reliabel \\
\hline
\end{tabular}

Dari hasil olahan dengan SPSS semua item Cronbach alph diatas 0,6 dan dapat di katakan reliabel.

\section{Pengujian Hipotesis}

Untuk menjawab Hipotesis penelitian dapat dilihat t-statistic pada Tabel berikut ini:

Tabel 2 Tabel Antar Konstruk

\begin{tabular}{|c|c|c|c|c|c|}
\hline & $\begin{array}{c}\text { Original } \\
\text { Sampel }\end{array}$ & $\begin{array}{c}\text { Sample } \\
\text { Mean }\end{array}$ & $\begin{array}{c}\text { Standar } \\
\text { Devition }\end{array}$ & T-Statistic & Keputusan \\
\hline $\begin{array}{c}\text { Lingkungan Kerja (X1)-> } \\
\text { Kepuasann Kerja(Y1) }\end{array}$ & 0.622 & 0.006 & 0.109 & 5.182 & Diterima \\
\hline $\begin{array}{c}\text { Lingkungan Kerja (X1)-> } \\
\text { Kinerja Karyawan(Y2) }\end{array}$ & $-0,006$ & $-0,017$ & 0.056 & 0.102 & Ditolak \\
\hline $\begin{array}{c}\text { Kepuasan Kerja (Y1)-> } \\
\text { Kinerja Karyawan(Y2) }\end{array}$ & 0.970 & 0.981 & 0.039 & 24.312 & Diterima \\
\hline
\end{tabular}


Untuk memperoleh $t$ tabel dengan level of confidence $95 \%$ atau $\propto=0,05$ dan degree of freedom $(\mathrm{n}-\mathrm{k}=40-3=37)$ dengan ketentuan apabila $t$ hitung $>t$ tabel, Ho ditolak dan Hi diterima dan sebaliknya apabila $t$ hitung $<t$ tabel, maka Ho diterima dan Hi ditolak.

$X_{1} k e Y_{1} \rightarrow$ Pengaruh $X_{1}$ ke $Y_{1}$ diperoleh dari $t$ tabel $(\propto=0,05$, df $(37))=t$ tabel $=1,684$, thitung $=4,780$. $t$ hitung $>t$ tabelmaka Ho ditolak, Hi diterima

\section{Pengujian Hipotesis 1}

Ho $: \propto_{1}=0 \rightarrow$ Tidak terdapat pengaruh signifikan Lingkungan Kerja (X1) terhadap Kepuasan Kerja (Y1)

Ha $: \propto_{1} \neq 0 \rightarrow T$ Terdapat Pengaruh signifikan Lingkungan Kerja (X1) terhadap Kepuasan Kerja (Y1)

Setelah dilakukan dibandingkan antara $\mathrm{t}$ tabel dengan $\mathrm{t}$ tabel, maka diperoleh $\mathrm{t}$ tabel $=1,684$, dan $t$ hitung $=5.182$ atau $t$ hitung $>t$ tabel, yang berarti bahwa Ha diterima, Ho ditolak atau dapat disimpulkan bahwa Lingkungan kerja berpengaruh signifikan terhadap Kepuasan Kerja.

\section{Pengujian Hipotesis 2}

Ho $: \beta_{1}=0 \rightarrow \quad$ Lingkungan Kerja (X1) tidak berpengaruh signifikan terhadap Kinerja Karyawan (Y2)

Ha $: \beta_{1} \neq 0 \rightarrow \quad$ Lingkungan Kerja (X1) berpengaruh signifikan terhadap Kinerja Karyawan (Y2)

Setelah dilakukan dibandingkan antara $t$ tabel dengan $t$ hitung, maka diperoleh $t$ tabel $=1,684, t$ hitung $=0,102$ atau $t$ hitung $<t$ tabel, Ho diterima, Ha ditolak atau dapat disimpulkan bahwa Lingkungan Kerja tidak berpengaruh signifikan terhadap Kinerja Karyawan

\section{Pengujian Hipotesis 3}

Ho $: \beta_{2}=0 \rightarrow \quad$ Kepuasan Kerja (Y1) tidak berpengaruh signifikan terhadap Kinerja Karyawan (Y2)

Ha $: \beta_{2} \neq 0 \rightarrow \quad$ Kepuasan Kerja (Y1) berpengaruh signifikan terhadap Kinerja Karyawan (Y2)

Setelah dilakukan dibandingkan antara $\mathrm{t}$ tabel dengan $\mathrm{t}$ hitung, maka diperoleh $t$ tabel $=1,684, t$ hitung $=24.312$ atau $t$ hitung $>\mathrm{t}$ tabel, Ho ditolak, Ha diterima dan disimpulkan bahwa Kepuasan Kerja (Y1) berpengaruh signifikan terhadap Kinerja Karyawan (Y2)

\section{HASIL DAN PEMBAHASAN}

\section{Pengaruh Lingkungan Kerja Terhadap Kepuasan Kerja}

Berdasarkan hasil penelitian diketahui bahwa lingkungan kerja mempunyai pengaruh terhadap kepuasan kerja yang positif, Ini berarti semakin baik lingkungan kerja yang mencakup suasana kerja, hubungan dengan rekan kerja, hubungan atasan dengan karyawan dan fasilitas kerja akan meningkatkan kepuasan kerja karyawan. Hal ini beralasan, bahwa setiap karyawan menginginkan lingkungan kerja yang baik dan sesuai yang mereka harapkan, baik itu meliputi lingkungan kerja fisik maupun lingkungan kerja non fisik. hal ini beralasan mengingat pada umumnya karyawan yang bekerja sangat memerlukan kenyamanan suasana kerja, dengan demikian gaji yang besar tidak serta merta membuat karyawan merasa puas, tapi ada hal yang dianggap lebih daripada itu, yaitu hubungan baik dengan atasan, rekan kerja ataupun bawahan. Pada umumnya hal ini dianggap karyawann merupakan hal yang utama, sehingga dalam penelitian memberikan pengaruh signifikan.

\section{Pengaruh Lingkungan Kerja terhadap Kinerja Karyawan}

Berdasarkan hasil penelitian diketahui bahwa Lingkungan Kerja berpengaruh tidak signifikan terhadap Kinerja karyawan.Ini menunjukkan bahwa karyawan yang ada dikantor masih kurang merasa puas dengan lingkungan ditempat mereka bekerja baik berupa fasilitas dan kenyamanan saat bekerja sehingga membuat karyawan dalam bekerja menjadi kurang maksimal. Hal ini beralasan, bahwa tentunya setiap karyawan menginginkan lingkungan kerja yang mereka tempati baik dan sesuai yang diharapkan dan inginkan oleh mereka, namunDengan lingkungan 
kerja non fisik yang baik akan memberi rasa nyaman, rasa tenang, rasa suka bagi semua karyawan dan dengan sendirinya, namun berbeda jika karyawan belum merasa puas dengan lingkungan disekitar meraka yang kurang mendukung yang menyebabkan kinerja tidak maksimal, sehingga beralasan hasil penelitian lingkungan kerja berpengaruh tidak signifikan terhadap kinerja karyawan.selain itu hal ini dibuktikan dengan besarnya cross loading pada indikator X1.3 (hubungan atasan dengan karyawan) yang berarti bahwa yang dianggap karyawan tidak berpengaruh signifikan terhadap kinerja karyawan adalah hubungan atasan dengan karyawan, atau lingkungan kerja ini lebih dilihat dari bagaimana atasan bisa menjalin hubungan baik dengan karyawan

\section{Pengaruh Kepuasan Kerja Terhadap Kinerja Karyawan}

Berdasarkan hasil penelitian diketahui bahwa Kepuasan Kerja mempunyai pengaruh terhadap Kinerja Karyawan yang positif, Ini berarti menunjukkan semakin baik Kepuasan kerja yang mencakup gaji, lingkungan kerja, atasan dan promosi jabatan, maka akan meningkatkan Kinerja Karyawan. Hal ini beralasan, bahwa kepuasan dalam bekerja itu diinginkan oleh setiap karyawan untuk meningkatkan kinerja mereka.dengan terpenuhinya rasa kepuasan dalam bekerja seperti kedudukan, pangkat, Umur dan mutu pengawasan dengan sendirinya karyawan akan merasa puas ditempat ia bekerja.sehingga beralasan hasil penelitian Kepuasan Kerja ini berpengaruh positip terhadap Kinerja Karyawan.

Pada hasil analisis terbukti bahwa Kepuasan Kerja berpengaruh positip dan signifikan terhadap Kinerja Karyawan, hal ini beralasan bahwa para karyawan yang bekerja di PT PLN (Persero) UPDK Mahakam sangat puas dengan kondisi di tempat karyawan bekerja baik dengan semua fasilitas maupun hubungan dengan rekan kerja sehingga meningkatkan kinerja mereka dalam bekerja.dengan demikian kepuasan kerja ini bukan hanya tentang mengenai situasi namun juga berhubungan dengan semua pekerjaan.Pada umumnya hal ini dianggap karyawann merupakan hal yang utama, sehingga dalam penelitian memberikan pengaruh signifikan. Selain itu hal ini dibuktikan dengan besarnya cross loading pada indicator Y1.3 (hubungan dengan rekan kerja) yang berarti bahwa yang dianggap karyawan sangat berpengaruh signifikan terhadap kepuasan kerja adalah hubungan dengan rekan kerja, atau kepuasan kerja ini lebih dilihat dari bagaimana atasan maupun karyawan memiliki hubungan baik dengan sesama rekan kerjannya dan terbukti signifikan, dan untuk loading faktor terendah yaitu Y1.1 (gaji) ini menunjukkan bahwa gaji yang karyawan terima masih kurang sesuai atas pekerjaan yang mereka kerjakan sehingga membuat mereka tidak puas dan mempengaruhi kinerja mereka.

\section{KESIMPULAN}

Setelah penulis melakukan perhitungan dengan menggunakan alat bantu PLS, pada bab IV sebagai bab analisis dan pembahasan tentang Pengaruh Lingkungan Kerja Terhadap Kepuasan Kerja Dan Implikasinya Terhadap Kinerja Karyawan pada PT PLN (Persero) UPDK Mahakam, maka penulis mengambil kesimpulan sebagai berikut :

1. Variabel Lingkungan Kerja (X1) berpengaruh signifikan terhadap Kepuasan Kerja Karyawan (Y1) pada PT PLN (Persero) Mahakam.

2. Variabel Lingkungan Kerja (X1) tidak berpengaruh signifikan terhadap Kinerja Karyawan (Y2) pada PT PLN (Persero) Mahakam.

3. Variabel Kepuasan Kerja(Y1) berpengaruh signifikan terhadap Kepuasan Kerja Karyawan (Y2) pada PT PLN (Persero) Mahakam.

\section{DAFTAR PUSTAKA}

Abdillah, W., \& Jogiyanto. (2015). Partial Least Square (PLS), Alternatif Structural, Equation Modelling (SEM) dalam penelitian bisnis. Jakarta: Andi.

al., H. e. (2010). Multivariate Data Analysis (7 ed.). Pearson Prentice Hall. 
Arikunto. (2006). Prosedur Penelitian Suatu Pendekan Praktis (Revisi ed.). Jakarta: Rineka Cipta.

Bungin, B. (2005). Metodologi Penelitian Kuantitatif Komunikasi, Ekonomi, dan Kebijakan Publik Ilmu-Ilmu Sosial Lainnya. Jakarta: Kencana.

christy, N. A. (2016, 11 23). Retrieved from https://www.google.co.id/amp/s/lingkunganhidup878.wordpress.com/2016/11/23pengerti an-dan-definisi-lingkungan-hidup-menurut-para-ahli/amp/.

Ghozali, I. (2008). Structural Equation Model Metode Alternatif dengan Partial Least Square $(P L S)$ (3 ed.). Semarang: Badan Penerbit Universitas Diponegoro.

Handoko. (2000). Manajemen Personalia dan Sumber Daya Manusia (2 ed.). Yogyakarta: BPFE.

Handoko, T. H. (2001). Manajemen, EdisiKetujuh. Yogyakarta: BPFE.

Handoko, T. (2000). Manajemen Personalia dan Sumber Daya Manusia (2 ed). Yogyakarta: BPFE.

Hasibuan, M. (2012). Manajemen Sumber Daya Manusia (Edisi ed). Jakarta: PT Bumi Askara.

Jogiyanto, \& Abdillah. (2009). Konsep dan Aplikasi PLS. Yogyakarta: BPEE-Yogyakarta.

Mangkunegara, A. P. (2009). Manajemen Sumber Daya Manusia Perusahaan. Bandung: PT Remaja Rosdakarya.

Marwansyah. (2010). Manajemen Sumber Daya Manusia. Bandung: Alfaberta.Robbins, Stephen P., dan Timothy.

Prawirosentono. (1999). Kebijakan Kinerja Karyawan. Yogyakarta: BPEE.

Rivai Veithzal. (2008). Manajemen Sumber Daya Manusia Untuk Perusahaan Dari Teori Ke Praktek. Jakarta.: PT. RAJAGRAFINDO PERSADA.

Rivai, V. (2005). Manajemen Sumber Daya Manusia Untuk Perusahaan Dari Teori Ke Praktik. Jakarta: PT. Raja Grafindo Persada. 